UDC: 373.5(091)(497.113 Sr. Mitrovica)

Ненад Лемајић

Универзитет у Новом Саду

Филозофски факултет

Одсек за историјуOdsek za istoriju

nenadlemajic@yahoo.com
Оригиналан научни рад

примљено: 1. јун 2013

прихваћено: 1. октобар 2013

\title{
МИТРОВАЧКА ГИМНАЗИЈА ИЗМЕЂУ ДВА СВЕТСКА РАТА*
}

Сажетак: На основу документације сачуване у Историјском архиву „Срем“ у раду се анализира развој Митровачке гимназије, најзначајније образовне институције у Сремској Митровици. Циљ рада је да укаже како је време између два светска рата било кључно за темељно организовање ове установе која ће постати расадник образовне и друге елите не само Сремске Митровице већ и шире. У раду се указује и на специфичности у спровођењу опште политике и идеологије у сфери образовања коју су спроводиле власти Краљевине Срба, Хрвата и Словенаца односно Југославије.

Кључне речи: Митровачка гимназија, Сремска Митровица, школске зграде, Момир Коруновић, Црвени крст, Јадранска стража.

Без обзира на изузетан углед Митровачке гимназије, дуго најзначајније институције образовања у граду а и у читавом Срему, о њеној прошлости не постоји превише историјских радова. У четрдесетак монографија, општих дела, расправа, забележених сећања, каталога, о Митровачкој гимназији се углавном говори тек успутно. Целовит рад о овој теми али квалитативно неуједначен написао је Радомир Прица, објавивши га у две верзије: Гимназија у Сремској Митровищи 1838-1958 (Сремска Митровица 1958) и Историја Митровачке гимназије до 1914 (Сунчани cam, 2001). Потом су Ђорђе Домазет и Ненад Лемајић објавили монографију 175 година Митровачке гимназије. ${ }^{1}$ За истраживање прошлости Гимназије стога је од највећег интереса архивски фонд Гимназија - Сремска Митровица (1838-1979), који се чува у Историјском архиву „Срем““ а састоји се од 257 књига и 198 кутија. ${ }^{2}$

\footnotetext{
* Текст је настао као фазни резултат рада на пројекту Војвођански простор у контексту европске историје (број 177002) Министарства просвете, науке и технолошког развоја Републике Србије и пројекту Средњовековна насеља на тлу Војводине. Историјски прочеси и догађаји (бр. 114-4512216/2011), који финансира Покрајински секретаријат за науку Владе Аутономне Покрајине Војводине.

1 За детаљан преглед литературе о Митровачкој гимназији вид. Ђорђе Домазет, Ненад Лемајић, 175 година Митровачке гимназије, Сремска Митровица 2013.

${ }^{2}$ Ова грађа је на немачком и српском, односно хрватском језику. Фонд садржи следећу грађу: Књиге
} 
Без обзира што се за формални почетак рада Гимназије узима 1838, она је почела да се претвара у школу гимназијског типа суштински тек од 1878. да би процес био завршен до 1918. године. Зато је за њено пуно устројство период између два светска рата био од највеће важности. Школски систем на територији Аустроугарске, односно у овиру ње хрватске државе, знатно је унапређен током друге половине деветнаестог века. Многе школе су се од реалки почеле претварати у реалне гимназије а неке и у класичне. О организацији школе у Митровици Антун Цувај наводи: ,„...Rješenjem od 11. svibnja 1887. [...] mala realka u Mitrovici počevši od školske godine 1887/88 postepeno pretvori u malu realnu gimnaziju. Zavod taj polazile su i djevojčice, a imao je istu nastavnu osnovu, što je imala realna gimnazija u Karlovcu u četiri donja razreda. To je bilo zavod srednjeg tipa, gdje svi učenici I i II razreda uče između ostalih predmeta latinski jezik. Od III razreda djelili su se učenici u gimnazijalce, koji uče latinski i grčki, i realce, koji umjesto tih jezika uče francuski jezik i mjerstveno crtanje“. ${ }^{3}$ Од 1895. III и IV разред се деле на класично и реално одељење. Реално одељење III разреда имало је следеће предмете: Хрватски, Немачки и Француски језик, Веронаука, Историја, Географија, Математика, Геометрија и геометријско цртање, Просторно цртање и Физика. Класично одељење је имало ове предмете: Хрватски, Немачки, Латински и Грчки језик, Веронаука, Географија, Историја, Математику, Физика и Просторно цртање. Постојали су и изборни предмети: Певање, Гимнастика, Ручни рад и Стенографија. ${ }^{4}$

До претварања Мале реалне гимназије у Велику реалну гимназију доћи ће постепено током друге деценије двадесетог века. Тако је 1910. године отворен V a 1911. и VI разред. При крају Првог светског рата отварају се 1917. VII разред и 1918. VIII разред. ${ }^{5}$ Тако је Гимназија добила осам разреда које ће задржати наредних четрдесетак година.

Током прве две године Првог светског рата, школске 1914/15. и 1915/16, школа није радила. После стварања Краљевине Срба, Хрвата и Словенаца школа ће наставити да ради по програму Троједне краљевине Хрватске, Славоније и Далмације да би 1925. била уједначена прва три разреда у свим гимназијама нове

\footnotetext{
записника од 1919. до 1979. године, укупно 62 књиге; поверљиве деловоднике 1927-1930, једну књигу; деловодне протоколе 1918-1976, 15 књига; остале књиге 1831-1979, 179 књига. Списи садрже: нормативне акте, записнике о полагању испита, молбе за полагање испита, податке о социјалној помоћи ученицима, документацију о стручним испитима вероучитеља и професора, годишње предрачуне, документацију о материјалним трошковима, финансијске планове, завршне рачуне, спискове ученика, сведочанства, решења о постављању и прекиду службе, решења о пензионисању, заклетве на верност у служби, досијее радника, спискове радника, платне спискове и друго. Фонд је у Историјски архив преузет у два наврата: први пут је 20. септембра 1963. године, непосредно од Гимназије, а потом после њеног привременог гашења 17. септембра 1982. године од Заједнице средњег образовања и васпитања

${ }^{3}$ Antun Cuvaj, Građa za povijest školstva Kraljevina Hrvatske i Slavonije od najstarijih vremena do danas, Zagreb 1908.

${ }^{4}$ Радомир Прица, Историја митровачке гимназије до 1914, Сунчани сат, 10, Сремска Митровица 2001, 177-178.

${ }^{5}$ Р. Прица, Историја митровачке гимназије до 1914, 178. Историјски архив Сремска Митровица, Градско поглаварство Сремска Митровица, Записник седница Градског заступства, књига 1.
} 
државе, последња генерација по старом програму завршава 1929. године. ${ }^{6}$

Крај Првог светског рата школа је дочекала као осморазредна (решењем од 7. октобра 1918) и у њој је одржан први испит зрелости. Првом испиту зрелости председавао је 27. фебруара 1919. као повереник Повереништва равнатељ (директор) Милан Зделар. ${ }^{7}$ Испиту зрелости су приступила два ванредна (екстерниста) ученика а положио је један, Марко Јовановић из Мостара у Херцеговини. Писмени задаци су рађени од 24. до 26. фебруара 1919, а били су следећи: из хрватског језика: „Мисли водиље илирског препорода особитим обзиром на данашње прилике“; из латинског језика: „C. Tacitus: Annal IV c. 6-7 forum et uis“; из немачког језика: „Die Naturkrafte im Dienste der Menschheit““. Решењем од 16. децембра 1919. Митровачка гимназија почиње да носи назив „Реална гимназија“. 8

Мада је редовна настава почела 3. септембра 1918, Гимназија је у два наврата прекидала рад. Први пут због шпанске грознице од 14. до 28. октобра а потом од 31. октобра до 11. новембра ради општих прилика и уласка српске војске на територију Аустроугарске монархије. Ученици и професори су 5. новембра заједно са грађанима присуствовали уласку српске војске у Митровицу. ${ }^{9}$

Период од 1918. до 1941. године

У школској 1918/19. школу је почетком године похађало 426 ученика, а на крају их је било 397. Међу њима је било 123 римокатолика, 283 православца, 6 гркокатолика, 5 евангелиста и 8 Јевреја (мојсијеваца). Међу ученицима који су похађали наставу из саме Митровице их је било $260 .{ }^{10}$ Први, други и трећи разред су имали по два одељења а преостали (IV до VIII) по једно. ${ }^{11}$ Од трећег разреда ученици су бирали да ли ће се уписати у реално-гимназијалне или реалне разреде. ${ }^{12}$

У складу са државном идеологијом која је поштовала моралне норме утемељене на религиозним начелима, сви ученици су имали обавезу да одлазе у цркву. Ради одржавања реда, директор је спрам броја ученика одређивао наставнике

\footnotetext{
${ }^{6}$ Радомир Прица, Гимназија у Сремској Митровици 1838-1958, Сремска Митровица 1958, 13.

${ }^{7}$ Извјештај Кр. реалне гимназије у Митровици за школску 1918/19, Загреб 1919, 10. Извештаји гимназије нису сачувани за све године. Извештаји се под називом Извештај за школску годину (са наведеном годином и без других ознака) чувају у Историјском архиву „Срем“ у Сремској Митровици и то деветнаест бројева за школске године 1918/19, 1929/30, 1931/32, 1934/35, 1935/36, 1937/38, 1938/39, 1939/40, 1945/46, 1946/47, 1947/48, 1956/57, 1959/60, 1960/61, 1961/62, 1962/63, 1971/72,1972/73, 1974/75, у Библиотеци „Глигорије Возаровић“ у Сремској Митровици двадесет бројева за школске године 1931/32, 1932/33,1934/35, 1935/36, 1936/37, 1937/38, 1945/46, 1946/47, 1947/48, 1955/56, 1956/57, 1957/58, 1960/61, $1962 / 63,1963 / 64,1964 / 65,1971 / 72,1972 / 73,1973 / 74,1974 / 75$, четири броја у библиотеци Митровачке гимназије за године $1933 / 34,1963 / 64,1971 / 72,1972 / 73$. и петнаест бројева у Музеју Срема 1936/37, 1945/46, 1946/47, 1955/56, 1956/57, 1957/58, 1958/59, 1959/60, 1960/61, 1963/64, 1964/65, 1971/72, 1972/73, 1973/74, 1974/75.

${ }^{8}$ Извјештај Кр. реалне гимназије у Митровици за школску 1918/19, Загреб, 1919, 10.

${ }^{9}$ Исто.

${ }^{10}$ Извјештај Кр. реалне гимназије у Митровици за школску 1918/19, Загреб, 1919, 17-18.

${ }^{11}$ Исто, 18-33.

${ }^{12}$ Исто, 35.
} 
задужене да их прате и да одржавају ред у цркви за време богослужења. ${ }^{13}$

Сви професори су полагали присегу краљу и држави која је гласила: „Ја, XY, заклињем се свемогућим Богом да ћу владајућем краљу Петру I Карађорђевићу, вјеран бити, да ћу се савјесно придржавати устава Краљевине Срба, Хрбата и Словенаца и да ћу дужност своју по законима и законским наредбама претпостављених ми области тачно и савјесно отправљати“. ${ }^{14}$

При директор (равнатељ) Гимназије у послератном периоду био је Милан Зделар. Напустио је Митровицу у лето 1920. и преселио се у Глину. ${ }^{15}$ У наредној школској години 1920/21. в. д. равнатељ је био професор Јосип (Јозеф) Таубел (Täubel), професор математике описног мерства и немачког језика. ${ }^{16}$ Њега је заменио нови директор Звонимир Магдић, од школске 1921/22. премештен из Краљевске реалне гимназије у Дарувару, а у Митровици је остао до 1926. Наставу у тим првим годинама није било једноставно организовати. Нови VII и VIII разред довели су до препуњености и недостатка простора који три постојеће зграде, две су носиле неформална али општеприхваћена имена: Сибирија и Палестина, нису могле задовољити. ${ }^{17}$ У тешким поратним годинама приоритет је био на обнови школског инвентара и комплетирању наставног колектива. Најстарији разреди су и даље имали два програма: реално-гимназијски и реални. Млађи разреди су имали по два одељења а дешавало се да одељења имају и преко шездесет ученика.

Октобра 1926. за директора Гимназије постављен је Стеван Рељић, инспектор Министарства просвете. ${ }^{18}$ Ступио је на дужност 6. октобра. ${ }^{19}$ Овај веома агилни директор се значајно ангажовао и око пропаганде за изградњу нове зграде а и у процесу уједначавања школског програма.

Гимназија је школске 1926/27. имала осам разреда са дванаест одељења и то по два од првог до четвртог разреда и једно од петог до осмог разреда. ${ }^{20}$

У складу са тенденцијом уједначавања програма на територији читаве Краљевине три године касније само је осми разред радио по плану из 1908. године. Тада VIII разред има два одељења: реално-гимназијско и реално одељење. Гимназијалци уче латински а не уче француски и нацртну геометрију, док реалци уче француски и нацртну геометрију, а не уче латински. ${ }^{21}$

\footnotetext{
${ }^{13}$ Историјски архив „Срем“, Гимназија - Сремска Митровица (даље: ИАС, Г - СМ), кутија 304, редовни списи, 5. новембар, 1925.

${ }^{14}$ ИАС, Г - СМ, књига 95, матична књига службеника 1912-1926.

${ }^{15}$ ИАС, Г - СМ, књига 70, Деловодни протоколи, Последњи помен је у протоколу везан за исплату селидбених трошкови 14. августа 1920.

${ }^{16}$ Исто; Извештај Кр. реалне гимназије у Митровици за школску 1918/19, Загреб 1919, 4.

${ }^{17}$ Сибирија је срушена када је изграђена нова зграда Гимназије а Палестина, која је добила име по јеврејској синагоги која се налазила прекопута ње до 1942. године, постоји и данас као депо Историјског архива „Срем“. Настава у њој се изводила до осамдесетих година двадесетог века. Централна зграда Гимназије била је садашња Зграда завода за заштиту споменика, иначе заштићена зграда позната као Потпуковников стан.

${ }^{18}$ ИАС, Г- СМ, Летопис гимназије: 1926-1933, књ. 1, стр. 1.

${ }^{19}$ Исто.

${ }^{20}$ Исто.

${ }^{21}$ Исто, књига 1, стр. 78.
} 
У школској 1930/31. Гимназију је похађало укупно 478 ученика (I разред 143, II - 76, III - 60, IV - 47, V - 34, VI - 43, VII - 40, VIII - 35). Први разред је имао три одељења други, трећи и седми разред по два одељења, остали по једно одељење. ${ }^{22}$ Од те школске године мења се наставни план и програм. Сасвим су изашле из школе генерације које су се школовале по програму из 1894. У први разред се уводи Француски језик, а у трећи Немачки и Хигијена; у четвртом разреду се укида Женски рад; у шестом и седмом се уводи Хигијена а неким предметима се смањује број часова.

Школски програм и разреди школске 1930/31:

\begin{tabular}{|c|c|c|c|c|c|c|c|c|c|c|c|c|c|c|c|}
\hline \multirow{2}{*}{$\begin{array}{c}\text { Ред } \\
\text { бр. }\end{array}$} & \multirow[b]{2}{*}{ Предмет } & \multicolumn{14}{|c|}{ Разреди и број часова на недељу } \\
\hline & & $\mathrm{I}^{\mathrm{a}}$ & $\mathrm{I}^{6}$ & $I^{\mathrm{H}}$ & $\mathrm{II}^{\mathrm{a}}$ & $\mathrm{II}^{6}$ & $\mathrm{III}^{\mathrm{a}}$ & $\mathrm{III}_{\sigma}$ & IV & $\mathrm{V}$ & VI & $\mathrm{VII}^{\mathrm{a}}$ & $\mathrm{VII}^{\sigma}$ & VIII & свега \\
\hline 1 & Веронаука & 2 & 2 & 2 & 2 & 2 & 2 & 2 & 2 & 2 & 2 & 1 & 1 & 1 & \\
\hline 2 & $\begin{array}{l}\text { Српско- } \\
\text { хрватски }\end{array}$ & 5 & 5 & 5 & 5 & 5 & 4 & 4 & 5 & 4 & 4 & 4 & 4 & 5 & 59 \\
\hline 3 & Француски & 3 & 3 & 3 & 3 & 3 & 3 & 3 & 3 & 3 & 3 & 3 & 3 & 3 & 39 \\
\hline 4 & Немачки & & & & & & 3 & 3 & 3 & 3 & 3 & 3 & 3 & 4 & 25 \\
\hline 5 & Латински & & & & & & & & & 4 & 4 & 3 & 3 & 3 & 17 \\
\hline 6 & Историја & & & & 2 & 2 & 3 & 3 & 3 & 3 & 3 & 3 & 3 & 3 & 28 \\
\hline 7 & Земљопис & 2 & 2 & 2 & 2 & 2 & 3 & 3 & 3 & 2 & 2 & 1 & 1 & 2 & 24 \\
\hline 8 & Природопис & 3 & 3 & 3 & 3 & 3 & & & & 2 & 3 & 2 & 2 & & 24 \\
\hline 9 & Хемија & & & & & & & & 3 & & & & & & 3 \\
\hline 10 & Физика & & & & & & 2 & 2 & & & & 3 & 3 & 3 & 13 \\
\hline 11 & Математика & 4 & 4 & 4 & 4 & 4 & 4 & 4 & 3 & 3 & 3 & 4 & 4 & 4 & 49 \\
\hline 12 & $\begin{array}{l}\text { Нацр. } \\
\text { геометрија }\end{array}$ & & & & & & & & & & & & & & \\
\hline 13 & Филозофија & & & & & & & & & & & 2 & 2 & 2 & 6 \\
\hline 14 & Хигијена & & & & & & 1 & 1 & 1 & & 1 & 1 & 1 & & 6 \\
\hline 15 & Цртање & 2 & 2 & 2 & 2 & 2 & 2 & 2 & 2 & 2 & 1 & & & & 19 \\
\hline 16 & Писање & 2 & 2 & 2 & 1 & 1 & & & & & & & & & 8 \\
\hline 17 & Гимнастика & 2 & 2 & 2 & 2 & 2 & 2 & 2 & 2 & 2 & 1 & & & & 19 \\
\hline 18 & Певање & 2 & 2 & 2 & 2 & 2 & & & & & & & & & 10 \\
\hline 19 & Женски рад & 2 & 2 & 2 & 2 & 2 & 2 & 2 & & & & & & & 14 \\
\hline & мушкарци & 27 & 27 & 27 & 28 & 28 & 28 & 28 & 29 & 30 & 30 & 30 & 30 & 30 & 415 \\
\hline & жене & 29 & 29 & 29 & 30 & 30 & 30 & 30 & 29 & 30 & 30 & 30 & 30 & 30 & 415 \\
\hline
\end{tabular}

Од почетка новембра 1930. повећан је број часова из Веронауке у VII и VIII разреду од 1 на 2 часа недељно. VII $^{\mathrm{a}}$, VII ${ }^{6}$ и VIII разреди су имали по 31 час недељно, а свега 418 часова. Уз додатних 6 часова Хорског певања, 4 часа Музике и 4 часа Веронауке за гркокатолике, евангелике и мојсијевце укупан број часова био је 432. Уз њих још 5 часова Гимнастике за женске, IV, V, VI разред, што је коначно 437 часова. $^{23}$

По препоруци Министарства просвете у Митровачкој гимназији су у употреби биле ћирилица и латиница јер су ученици морали равноправно знати оба писма а што се употребе наречја тиче закључено је: „..пошто се у Сремској

\footnotetext{
${ }^{22}$ Исто, књига 1, стр. 97.

${ }^{23}$ Исто, књига 1, стр. 97-98.
} 
Митровици употребљавају оба наречја, али ипак екавштина у већој мери, да се опћенито употребљава екавско наречје, али да се ученицима допушта да се могу служити и ијекавштином“. ${ }^{24}$

У овом периоду на подручју Срема и Сремске жупаније, касније области, Митровачка гимназије је била један од темељних стубова система образовања. Поред ове гимназије постојале су и гимназије у Земуну (мушка и женска), Руми, Сремским Карловцима, Вуковару, Винковцима и Илоку. ${ }^{25}$

Два нова разреда, VII и VIII, и претварање школе у велику реалну гимназију створило је проблем везан за неадекватан школски простор и недовољан број учионица. Настава се одвијала у три зграде ${ }^{26}$ и није чудно што се питање отварања школског објекта наметало тих година. Игром политичких прилика гимназијски вероучитељ Милан Миличић био је 1926. и 1927. градски начелник. Он је питање зидања зграде наметнуо као приоритетно. Пошто у градској каси малог града није било довољно новца за такав подухват, требало је наћи додатна средства. У то време је Петроварадинска имовна општина ${ }^{27}$ донела одлуку о подизању споменика краљу Петру I Карађорђевићу. Градоначелник је предложио да се будућа зграда гимназије посвети успомени на великог краља ујединитеља. Овај предлог је прихваћен и донета је одлука да се подигне просветни дом под именом краља Петра I Великог Ослободиоца. Обезбеђен је потребан новац а затим је уз много труда и сагласност Министарства просвете и Управе државних добара. ${ }^{28}$

Нова (садашња) зграда Митровачке гимназије пројектована је као и све зграде од државног значаја у Министарству грађевина у Београду 1928. године. Пројектовао ју је архитекта Момир Коруновић. Поред тога што је била гимназијска зграда, грађена је и као споменик краљу Петру I Карађорђевићу. Био је то први Коруновићев пројекат на тлу Војводине. Замислио га је у монументалнијој форми, као двоспратну палату са три фасаде окренуте улици и једном према дворишту. Током завршних припрема радова на згради одустало се, вероватно због финансијских ограничења, од неких Коруновићевих романтичарскоекспресионистичких замисли. Измене у смислу поједностављења неких решења извршио је општински инжењер Бошко Стојановић. Поред значајних додатака и интервенција Стојановића зграда Гимназије - несумњиво по основној замисли простора, општој композицији простора, детаљима приземља и другим елементима - остаје Коруновићево дело. ${ }^{29}$ Уговор са извођачем Јосипом Волером склопљен је

\footnotetext{
${ }^{24}$ ИАС, Г - СМ, кутија 304, редовни списи, 4. јун 1929.

${ }^{25}$ ИАС, Г- СМ, кутија 304, редовни списи, 27. мај 1929.

${ }^{26}$ Две од њих су колоквијално називане Палестина и Сибирија, вид. Кирил Свинарски, Нешто као успомене давне, Сунчани сат 7, Сремска Митровица 1997, 164.

27 Данас бисмо имовну општину најпре могли поредити са Јавним предузећем које води рачуна о водама и шумама на неком подручју. Седиште Петроварадинске имовне општине било је у згради на Тргу Ћире Милекића, где је сада смештена Управа полиције за Срем.

${ }^{28}$ О проблемима који су настали током затварања финансијске конструкције и прибављања дозвола вид. детаљно: Душан Познановић, Други у аутобиографији, Записи о наставницима и Ђаиима Митровачке гимназије, Сремска Митровица 1998, 12-14; Д. Познановић, Митровачка гимназија - споменик краљу Петру I, (I-IV), Сремске новине, 25. 9, 2. 10, 9. 10, 16. 10. 1991.

${ }^{29}$ Александар Кадијевић, Арх. Момир Коруновић, пројектант зграде Митровачке гимназије, Сунчани сат
} 
23. јуна 1928. а два дана касније су отпочети и радови. ${ }^{30}$

Оданост династији а посебно краљу Петру била је тада део државне реторике и идеологије. Поготово су се споменици краљу подизали у новоослобођеним (пречанским) крајевима. Подизање зграде уместо споменика било је пре изузетак него правило. ${ }^{31}$

Зграда је завршена априла 1930. о трошку Градске општине Сремска Митровица. Значајну помоћ дала је и Петроварадинска имовна општина у износу од 1.500 .000 динара. Грађевински трошкови објекта дужине 73,5 метра износили су 3.637 .685 динара и 33 паре. ${ }^{32}$ Свечано освећење је обављено 15. јуна а гимназијалци су у клупе нове школе сели 17 . септембра $1930 .{ }^{33}$ у једном документу остао је забележен и податак да је зграду изградио познати митровачки градитељ Рудолф Волер. ${ }^{34}$

Формализовање новог назива извршено је Указом Његовог величанства краља од 11. марта 1929, од када Гимназија носи име Државна реална гимназија краља Петра I Ослободиоца. ${ }^{35}$

Тек што је Гимназија почела да ради у новој згради, 29. марта 1931. изненада је пензионисан директор Стеван Рељић. Разлог за превремено пензионисање (имао је само 24 и по године службе) је наводно био покушај атентата који је један ученик извео на професора Перенчевића годину дана раније. ${ }^{36}$ Примопредаја дужности директора обављена је комисијски 17. и 18 април 1931. За в. д. директора је постављен професор Драгољуб Николић. ${ }^{37}$ Протећи ће више од две године до постављања новог директора. Драгољуб Николић је био в. д. директор до новембра следеће године. Тада је из Руме 25. октобар 1932. премештен професор

6, Сремска Митровица 1996, 196-198.

30 Д. Познановић, Други у аутобиографији, 15-17.

31 Тако је Велики Бечкерек (данашњи Зрењанин) у периоду од 1935. до 1941. и од 1944. до 1946. носио назив Петровград. Споменици краљу подигнути су у низу места (Сарајеву 1923, Панчеву 1934, Дубровнику 1924, Зрењанину и другим местима, а у Високом је отворен Соколски дом у славу краља Петра). Краљ Петар I Карађорђевић (познат и као краљ Петар Ослободилац и Стари краљ) рођен је као пето дете кнеза Александра и кнегиње Персиде (из чувене породице Ненадовић) из Бранковине, на Петровдан, 29. јуна / 11. јула 1844. године. Крунисан је 21. септембра 1904. године после свргавања са престола Србије дотадашње династије Обреновић. Умро је 16. августа 1921. у Београду, а сахрањен је у својој задужбини на Опленцу.

32 Петар Милошевић, Душан Вулетић, Бора Чекеринац, Радомир Прица, Сремскомитровачка хроника, Нови Сад 1987, 108; Историјски архив Босне и Херцеговине, Краљевска банска управа Дринске бановине, пов. 1678/1930.

${ }^{33}$ Д. Познановић, Други у аутобиографији, 18.

${ }^{34}$ П. Милошевић, Д. Вулетић, Б. Чекеринац, Р. Прица, Нав. дело, 108; Архив Војводине, Банска управа Дунавске бановине, Ф, 126, II 25554/33.

${ }^{35}$ ИАС, Г - СМ, Летопис гимназије: 1926-1933, књ. 1, стр. 57.

${ }^{36}$ ИАС, Г - СМ, Летопис гимназије: 1926-1933, књ. 1, стр. 116. Одлука о пензионисању носи датум 3. април 1931. (Извештај за школску годину 1930/31, Државна реална гимназија Краља Петра I Великог Ослободиоца Сремска Митровица, 4).

${ }^{37}$ ИАС, Г - СМ, Летопис гимназије: 1926-1933, књ. 1, стр. 117. Одлука министра просвете од 28. априла 1931 (Извештај за школску годину 1930/31, Државна реална гимназија Краља Петра I Великог Ослободиоца Сремска Митровица, 3). 
Стјепан Ловрић, који је потом 2. новембра 1932. именован за в. д. директора школе. ${ }^{38}$ Трајније решење је пронађено тек следеће године, када је 2. августа 1933. Михајло Симић, професор Прве мушке гимназије у Београду, постављен за директора гимназије у Митровици. ${ }^{39}$ Он ће на месту директора гимназије остати до 8. априла 1941. Министарство просвете је често премештало професоре из школе у школу а изузетно велик број професора био је премештан баш у ово време. Тада у Митровачку гимназију долази десет нових професора. Одлуком Министарства просвете четворо је премештено из Београда, двоје из Новог Врбаса, а по један из Сплита, Ужица, Руме и Крушевца. На рад у Гимназију додељена су два професора, из Ужица и Никшића. Десет професора је послато у друге гимназије, два у Нови Сад а остали у Београд, Крушевац, Нови Пазар, Чачак, Шабац и Никшић. Доскорашњи в. д. директора Стјепан Ловрић послан је у Загреб. На рад у друге школе упућено је осам професора суплената, и то седам у Београд а један у Књажевац. Тако се значајан део колектива у овој школској години променио. ${ }^{40}$

Тих година је дошло и до стабилизације броја ученика, на око 500, односно преко 60 по разреду. Тако је 1932. године уписано 494 ученика. ${ }^{41}$

Међу ученицима Гимназије било је и јеврејске деце. У школској 1910/11. години је из јеврејске митровачке заједнице, која је бројала око 300 људи, 11 деце, како се званично бележило, мојсијеве вероисповести похађало наставу. ${ }^{42}$ Пред Други светски рат, када је заједница у граду имала тек нешто више од 100 припадника, 13 ученика је похађало наставу у Гимназији. ${ }^{43}$

У оквиру школе тридесетих година је постојало неколико удружења чији циљ је био везан за побољшање услова живота и рада ученика или за од државе подстицано утврђивање југословенске идеологије. Тако је постојала Заједница дома $\boldsymbol{u}$ иколе чији је циљ био обезбеђивање средстава за набавку часописа, учила и књига и брига о моралним вредностима које је требало пренети деци. Заједница је постојала од 1931. године а председник је био Људевит Веслај. Она је омогућила да школа држи часописе Српски књижевни гласник, Гласник Историјског друштва у Новом Саду, Летопис Матице српске, Венац и Младост, као и издања Српске књижевне задруге и Матице хрватске. Значајним средствима је омогућен и пут на Опленац 27. маја 1935. године. ${ }^{44}$

Бачка книжевна дружина „Будућност“ формирана 1921. године. ${ }^{45}$ Окупљала је децу склону књижевности и читању. Њихове активности биле су повезане са радом библиотеке која је имала 1.155 књига. Дружина је школске

\footnotetext{
${ }^{38}$ ИАС, Г- СМ, Летопис гимназије: 1926-1933, књ. 1, стр. 139.

${ }^{39}$ ИАС, Г - СМ, Летопис гимназије: 1933/34-1940/41, књ. 2, стр. 3 ( У овој књизи летописа има података за ратни период али и за прве три године после Другог светског рата). Директор Михајло Симић је био пореклом из Босанског Шамца (ИАС, Г - СМ, кутија 316, редовни списи, 1941).

${ }^{40}$ ИАС, Г - СМ, Летопис гимназије: 1933/34-1940/41, књ. 2, стр. 4-7.

${ }^{41}$ ИАС, Г - СМ, Летопис гимназије: 1926-1933, књ. 1, стр. 137.

${ }^{42}$ Jovanka Dražić, Jevreji и Mitrovici, Sremska Mitrovica 1998, 12, 26-29; Историјски архив „Срем“, Главни каталог Краљевске мале реалне гимназије за годину 1910/11, књ. 130.

${ }^{43}$ Jovanka Dražić, Jevreji u Mitrovici, 12, 28.

${ }^{44}$ Извештај за школску годину 1934/35, 31-33.

${ }^{45}$ Извештај за школску годину 1935/36, 31.
} 
1934/35. одржала 10 састанака на којима је прочитано 45 радова. $^{46}$ Њен рад је усмеравао професор српскохрватског језика Бошко Новаковић. ${ }^{47}$

Подружница Феријалног савеза основана 1919. године ${ }^{48}$ имала је задатак да својим члановима омогући путовање и опоравак за време школског одмора широм тадашње државе по повољним ценама. Имала је око шездесет чланова а рад је усмеравао професор историје и земљописа Јанко Ердељи. ${ }^{49}$

Подмладак Црвеног крста у Гимназији је основан 1923. године. ${ }^{50} \mathrm{y}$ школском одбору су се по функцији налазили директор, као председник, и разредне старешине. Подмладак је био део Среског одбора Црвеног крста. Сваке године у другој половини септембра одржавана је недеља Црвеног крста у оквиру које је образована велика поворка кроз град и у њој су учествовали директор, сви наставници и ученици. На челу поворке је ношена застава гимназијског Подмлатка Црвеног крста. Обично се поворка заустављала у градском парку и ту су певане родољубиве песме. Чланова је било преко 500, што значи готово сви ученици. Новац од чланарине је највећим делом слан Дунавском бановинском одбору Друштва Црвеног крста. ${ }^{51}$ У првој половини 1938. године Подмладак је у школи организовао Самарјански течај која су похађала 34 слушаоца. ${ }^{52}$ Шеф течаја је била госпођица др Загорка Радоњић. ${ }^{53}$

Приликом прославе Штросмајеровог дана 4. фебруара 1932. основана је у Митровачкој гимназији и организација Поджладак Јадранске страже. Организација за промицање мора и поморства Јадранска стража основана је 1922. године са седиштем у Сплиту, на иницијативу национално освешћених интелектуалаца, сплитских родољуба. ${ }^{54}$ Повереник Јадранске страже у Гимназији је био професор историје и земљописа Јосип Хруш. ${ }^{55}$ Јадранска стража је пропагирала идеје националног јединства у одбрани Јадранског мора и била је важна полуга у стварању интегративног југословенства ослоњеног на југословенски оријентисане Хрвате у Далмацији. Подмладак је имао између 150 и 230 чланова а тесно је сарађивао и са Месним одбором Јадранске страже у граду којим је руководио инж. Људевит Веслај. Подмладак и месни одбор су 31. октобра 1935. приредили у Соколском дому „Дане Јадранске страже“. ${ }^{56}$ Један број ученика је слан на летовање у летовалиште Јадранске страже у Бијелој. ${ }^{57}$ Од месног одбора Јадранске страже из

\footnotetext{
${ }^{46}$ Извештај за школску годину 1934/35, 33.

${ }^{47}$ Извештај за школску годину 1935/36, 31.

${ }^{48}$ Исто.

${ }^{49}$ Извештај за школску годину 1939/40, 32-33.

${ }^{50}$ Извештај за школску годину 1935/36, 32.

${ }^{51}$ Исто.

52 Ови курсеви су служили за обуку у помоћи људима у случају опасности.

${ }^{53}$ Извештај за школску годину 1937/38, 52.

54 Mirja Lovrić, Prilog poznavanju izdavačke djelatnosti Jadranske straže iz fonda knjižnice Hrvatskoga pomorskoga muzeja u Splitu, Baština 35, Split 2009, 356; Norka Machiedo Mladinić, Jadranska straža 1922.1941., Zagreb 2005.

${ }^{55}$ Извештај за школску годину 1937/38, 27-28.

${ }^{56}$ Извештај за школску годину 1935/36, 33.

${ }^{57}$ Извештај за школску годину 1937/38, 27-28.
} 
Митровице гимназијски подмладак је 1939. добио и своју заставу. ${ }^{58}$

У Гимназији је повремено радило и Коло трезвене младежи „Просвета“ основано 1921, а рад му је обновљен 1933. Оно је одржавало повремене приредбе а 1935. је имало 75 чланова. ${ }^{59}$

Интересовање за техничку модернизацију довело је 1937. године до формирања Подмлатка Аеро-клуба „Наша крила“ чијим радом је координирао професор физике, математике и хемије Радован Симуновић а потом професори Теохар Караџић и Алексије Петровић. У оквиру рада држана су предавања о авијацији. $^{60}$ Чланови подмлатка су 14. маја 1939. посетили Београд и Земун. У Земуну су посетили војни аеродром, где им је одржано предавање а посетили су аеро-пут и аеро-клуб. ${ }^{61}$

У годинама пред Други светски рат у Гимназији је формирана значајна књижница (библиотека) која се делила на наставнички део са 2.580 свезака и ђачки са 3.421 насловом. $^{62}$

У оквиру школе постојала су и четири фонда:

1. Фонд за помагање сиромашних ученика - 27. мај 1928,

2. Екскурзиони фонд - основан 16. маја 1928,

3. Школски фонд и

4. Фонд здравствене заштите ученика.

Међу добротворима Фонда за помагање сиромашних ученика помињу се и познати српски индустријалци из Београда Ђорђе Вајферт и Игњат Бајлони. Радом фондова су значајно олакшавани проблеми са којима се школа суочавала током радне године. ${ }^{63}$

\section{Литература:}

Домазет, Ђорђе - Лемајић, Ненад, 175 година митровачке гимназије, Сремска Митровица 2013.

Dražić, Jovanka, Jevreji u Mitrovici, Sremska Mitrovica 1998.

Кадијевић, Александар, Арх. Момир Коруновић, пројектант зграде Митровачке гимназије, Сунчани сат 6, Сремска Митровица 1996.

Lovrić, Mirja, Prilog poznavanju izdavačke djelatnosti Jadranske straže iz fonda knjižnice Hrvatskoga pomorskoga muzeja u Splitu, Baština 35, Split 2009.

Machiedo Mladinić, Norka, Jadranska straža 1922.-1941., Zagreb 2005.

\footnotetext{
${ }^{58}$ Извештај за школску годину 1938/39, 30; Застава је освећена 7. маја 1939.

${ }^{59}$ Извештај за школску годину 1935/36, 34 .

${ }^{60}$ Извештај за школску годину 1937/38, 28; Извештај за школску годину 1938/39, 30-31; Извештај за школску годину 1939/40, 33.

${ }^{61}$ Извештај за школску годину 1938/39, 30.

${ }^{62}$ Исто, 31.

${ }^{63}$ Извештај за школску годину 1938/39, 34-37.
} 
Милошевић, Петар - Вулетић, Душан - Чекеринац, Бора - Прица, Радомир, Сремскомитровачка хроника, Нови Сад 1987.

Познановић, Душан, Други у аутобиографији, Записи о наставнищима и ђацима Митровачке гимназије, Сремска Митровица 1998.

Прица, Радомир, Гимназија у Сремској Митровици 1838-1958, Сремска Митровица 1958.

Прица, Радомир, Историја митровачке гимназије до 1914, Сунчани сат 10, Сремска Митровица 2001.

Свинарски, Кирил, Нешто као успомене давне, Сунчани сат 7, Сремска Митровица 1997.

Cuvaj, Antun, Građa za povijest školstva Kraljevina Hrvatske i Slavonije od najstarijih vremena do danas, Zagreb 1908. 


\title{
THE GYMNASIUM OF SREMSKA MITROVICA BETWEEN THE WORLD WARS
}

\begin{abstract}
Summary
The Gymnasium of Mitrovica is the most significant educational institution in its city. It formed gradually during the $19^{\text {th }}$ century, experiencing its apex immediately after World War I when the city became part of the newly formed Kingdom of Serbs, Croats and Slovenes (Yugoslavia). The increasing number of students and classes called for a suitable building. The construction of the building at the start of the 1930s played a significant role in the urbanisation of the city. Instructors from today's Serbia and Croatia contributed greatly to the quality and renown of the school.
\end{abstract}

Keywords: Gymnasium of Mitrovica, Sremska Mitrovica, school building, Momir Korunovič, Red Cross, Adriatic Guard. 